\title{
Evaluation of Orange Peel Citrus Sinensis (L) as a Source of Repellent, Toxicant and Protectant against Zabrotes Subfasciatus (Coleoptera: Bruchidae)
}

\author{
Dawit Kidane Zewde ${ }^{{ }^{*}}$ and Bekelle Jembere ${ }^{2}$ \\ ${ }^{1}$ Department of Biology, College of Natural and Computational Sciences, Mekelle University, \\ P.O. Box 3179, Mekelle, Ethiopia (*dawitom14@yahoo.com) \\ ${ }^{2}$ Department of Biology, Science Faculity, Addis Ababa University, P.O.Box 1176, Addis \\ Ababa, Ethiopia. (bekeleja@Yahoo.com)
}

\begin{abstract}
Continued application of synthetic insecticides arise development of resistance and pollution of the environment. Laboratory experiments were conducted to test the efficacy of products of orange (Citrus sinensis) peels in the control of the stored products beetle Zabrotes subfasciatus (L) in stored haricot beans (latin name). Different levels of the extracts and essential oil of Citrus sinensis was tested. Conventional synthetic insecticide, Pirimiphos-methyl, was used as a standard check. Toxicity potential of different extracts of $C$. sinensis was tested against $Z$. subfasciatus. Extracts prepared using different solvents against the beetles were not toxic. However, essential oils at highest rate of $750 \mathrm{mg}$ applied at $3 \mathrm{ml}$ per filter paper gave $100 \%$ mortality after $24 \mathrm{~h}$. Beans treated with $15 \mathrm{~g}$ of sun dried powder of orange peel and $750 \mathrm{mg}$ of essential oil killed $65 \%$ and $67 \%$ of Z. subfaciatus after 96 hours respectively. Powders from ground peels caused significant reduction in progeny emergence of $Z$. subfasciatus $(\mathrm{P}<0.05)$. There was no progeny produced when essential oil was used, even at lower dosage levels of 30mg. All the treatments were repellent to Z. subfasciatus. The essential oil of orange peel had a high level of toxicity in the fumigation bioassay against $Z$. subfasiatus.
\end{abstract}

Key words: Citrus sinensis, essential oil, Zabrotes subfasciatus, Pirimiphos-methyl, Percent weight loss, Damage assessment.

\section{INTRODUCTION}

Globally a minimum of $10 \%$ of cereals and legumes are lost after harvest (Boxall et al., 2002). Insect pests cause heavy economic losses to stored grains throughout the world and their impacts are more devastating in poor countries (Boxall et al., 2002). The two most universal and potent[important] pests in pulse storage are the Mexican bean weevil, Zabrotes subfasciatus (Boheman) and the common bean weevil Acanthoscelides obtectus (Say) in Africa (Slim, 1993).

Ferede and Tsedeke (1995) reported that these two species are the major pests of stored beans in Ethiopia. The study conducted in Bako recorded 14\% of total loss by Z. Subfasciatus in haricot been stored for 12 month (Adane and Abrham, 1996). Infestation by Z. subfasciatus can cause a loss of about $12 \%$ of the available protein (Mc Farlance, 1988).

Control of stored products insect pests rely heavily on hazardous synthetic productd. The increasing problems associated with the use of synthetic chemicals for the control of stored 
products insects necessitates the development of safe repellent agents against stored products pests. Many workers, including developing countries have taken the lead in this quest (Jilani et al., 1988; Cobbinhah and Appiah-Kwarteng, 1989; Jembere et al., 1995; Mekuria, 1995; Adane and Abrham, 1996; Bayeh and Tadesse, 1996; Bekele et al., 1997; Firdissa and Abrham, 1998; Emana, 1999; Glob et al., 1999).Use of plant products as insecticide is one of the important approaches of insect pest management and it has many advantages over synthetic insecticides (Weinzierl and Henn, 1992). Plant materials with insecticidal properties are one of the most important locally available, biodegradable and inexpensive methods for the biological control of pests. provide small-scale farmers with locally available, biodegradable and inexpensive method for the control of pests of stored products. Considering the importance of plant insecticides, the [F]farmers of [ in] Ethioipia treat their stored products with local herbs to reduce storage losses due to pests (Yemane and Yilma, 1998). Firdissa and Abrham (1999) reported that Chenopodium $s p$. performed very well and resulted in high percentage of adult mortality, reduced progeny emergence and low percent grain damage. Bayeh and Tadesse (1996) found that neem (Azadirachta indica), birbira (Milletia sp.) oil and the powder of pyrethrum flower are toxic against Callosobruchus chinensis. Cow pea treated with the powder of orange peels is associated with $\mathrm{LD}_{50}$ of $4 \%(\mathrm{w} / \mathrm{w})$ for Callosobruchus maculates (F.) exposed to it (Don Pedro, 1985). Essential oil derived from orange peels is known to have toxic, feeding deterrent, and poor development effects on lesser grain borer, Rhyzoperta domonica (F.), rice weevils, Sitophilus oryzae (L.) and red floor beetle, Tribolum castaneum (Herbst) (Tripathi et al., 2003). The peel oil was also reported to have toxicity toward Culex pipiens (Mwaiko and Savaeli, 1992); and cow pea weevils, Callosobruchus maculates (F.) (El-sayed and Abdel-Razik, 1991). Further more, the peel oil has fumigant action against fleas (Weinzierl and Henn, 1992) and house hold insects Blatella germanica (L.) and Musca domestica (L.) and stored product Sitophilus oryzae (Karr and Coats, 1988). Other plants that have been reported to repel pests of stored products include Croton macrostachyus, Ricinus communis, Datura stramonium, Cpsicum frutescens, Azadirchata indica, Ocimum sp. and Eucalypyus sp. (Jembere et al., 1995; Emana, 1999; EARO, 1999; El Altta and Ahmed, 2002). Considering the importance of plant insecticides in the pest management, the present work is designed to investigate the efficacy of the products of orange peels in the control of the pulse grains insect Zabrotes subfasciatus. 


\section{MATERIALS AND METHODS}

\subsection{Insects culture}

Adults of Z. subfasciatus (Boheman) brought from Melkassa Agricultural Research Center were cultured at Department of Biology, University of in Addis Ababa, Insect Science insectory at 27 $\pm 3^{\circ} \mathrm{C}$ and 55-70\% RH (Schoonven, 1978). Whole haricot bean seeds bought from local farmers from Melkassa south of Addis Ababa were kept in an oven at $60^{\circ} \mathrm{C}$ for 6 hrs to disinfest the seeds from any prior infestation before using them as a substrate for insect rearing (Jembere, 2002). Fifty pairs of the adult of $Z$. subfasciatus were placed in 1-litre glass jars containing $250 \mathrm{~g}$ seeds. The jars were then covered with nylon mesh that was held in place with rubber bands. The parent bruchids were sieved out after an oviposition time of 13 days. Then the seeds were kept under laboratory condition until F1 progeny emergence. The F1 progeny, which emerged after 30 days, were sieved out and used for the experiment.

\subsection{Plant material collection and extraction}

\subsubsection{Solvent extract of plant materials}

Fresh orange fruit (Valencia variety) brought from the Awash agro industry, were peeled and chopped with a knife and then soaked in distilled water, petroleum ether, ethanol and acetone at the rate of $10 \mathrm{~g} / 100 \mathrm{ml}, 20 \mathrm{~g} / 100 \mathrm{ml}$ and $30 \mathrm{~g} / 100 \mathrm{ml}$ of each solvent for extraction (Jembere, 2002). After 24 hours the mixtures were filtered with cheese cloth and filter paper (Watman No 9). Then the filtrates were ready to be used for the different treatments.

\subsubsection{Dried and ground materials}

The fresh orange peels of $C$. sinensis were dried under shade. Ground materials were obtained by grinding the dry peels into a fine powder using mortal and pestle. The rates used were $5 \mathrm{~g}$ (2\%), $\log (4 \%)$ and $15 \mathrm{~g}(6 \%) / 250 \mathrm{~g}$ of grains.

\subsubsection{Isolation of essential oil extract}

Essential oil of $C$. sinensis was isolated by hydrodistillation of fresh orange peels using a Clevenger type apparatus. An average yield of $7.4 \mathrm{ml}$ oil was collected from $1 \mathrm{~kg}$ of orange peel. The oil was kept in refrigerator for later on use. At the time of use the oil was weighed in three doses of 30mg, 150mg and 750mg and dissolved in 10ml of acetone.

\subsection{Assessment of Toxicity, Progeny and Damage}

Different levels of the extracts and essential oil were applied to a filter paper of $9 \mathrm{~mm}$ diameter at the rate of $1 \mathrm{ml}, 2 \mathrm{ml}$ and $3 \mathrm{ml}$ per filter and placed in a Petri dish of $10 \mathrm{~cm}$ diameter. In the case of 
organic solvent extracts, the treated filter was exposed to the open air to allow the organic solvent to evaporate. Then, $1 \mathrm{ml}$ of distilled water was added to the entire surface of the each treated filter papers, as a carrier of the extracts. Variable exposure times were considered, which was based on the nature of the solvent. In case of acetone and petroleum ether the exposure time was 30 minutes, while it was 60 minutes for ethanol (Jembere, 2002). Other filter papers were also treated with three levels of different solvents as control. After treatment, 5pairs of 3-7 dayold adults of both sex of $Z$. subfasciatus were introduced into the treated and control filter papers in the petri dishes. The treatments were replicated three times. Mortality of the adult insects were counted after 24, 48, 72 and 96hrs.

For powder treatment, $250 \mathrm{~g}$ of disinfected haricot bean seeds were introduced into three $1 \mathrm{~L}$ glass jars that were treated differently with the powdered orange peels (i.e. 5, 10 and $15 \mathrm{~g}$ of the powder). The grains of Pirimiphos-methyl treated and untreated were included as standard check and control, respectively. After treatment, 20, three to seven day old Z. subfsciatus of mixed sex were introduced to the treated and untreated seeds in the glass jars. The jars were covered with nylon mesh and held in place with rubber bands. The number of dead insects in each jar was sieved and counted after 24, 48, 72 and 96 hrs.

The treated jars were kept for additional 10 days of oviposition time after mortality assessment. All live and dead insects were sieved and discarded after 13 days of introduction. The treated and control grains were then kept until emergence of F1 progeny. Then the number of F1 progeny produced by Z. subfasciatus was counted. Counting was stopped after 45 days from the day of introduction to avoid overlapping of generation.

Damage assessment was carried out on treated and untreated grains. Samples of 100 grains were taken from treated and untreated grains and the number of damaged (grains with characteristic holes) and undamaged grains were counted and weighed. Percent weight loss was calculated by count and weight method cited in FAO (1985) as:

$$
\% \text { Weight loss }=\underline{(\mathrm{UaN}-(\mathrm{U}+\mathrm{D}) \times 100}
$$

$$
\mathrm{UaN}
$$

Where $\mathrm{U}=$ weight of undamaged fraction in $\mathrm{n}$ the sample, $\mathrm{N}$.

$\mathrm{N}=$ total number of grains in sample.

$\mathrm{Ua}=$ average weight of one undamaged kernel.

$\mathrm{D}=$ weight of damaged fraction in $\mathrm{n}$ the sample

The assessment was replicated five times for each treatment. 


\subsection{Repellency bioassay}

The repellent action of the ground peel and essential oil of C. sinensis against Z. subfasciatus were assessed in a choice and with no choice bioassay system in a ' $\mathrm{Y}$ ' olfactometer. In choice test, hundred grams of untreated disinfected haricot bean for Z. subfasiatus were put into one of the gas washing bottle, while differently treated seeds were put in the other gas washing bottle. For no choice test, one of the gases washing bottle was left empty. Then air was pumped with regulated air pump at a rate of $1.2 \mathrm{l} /$ minute into a gas washing bottle containing activated charcoal for filtration through rubber tubing. The filtrated air then passes to the two washing gas bottles containing untreated and treated seeds or with no seeds. Finally the air reaches the two arms of the "Y" tube glass which is attached to the stem where the insects are released. After this set up following the method of Jembere et al. (1995), twenty five adults of each Z. subfasiatus of mixed sex and age were released into the " $\mathrm{Y}$ " olfactometer glass. After 30minutes, the numbers of insects which moved into the untreated (Nc) and treated bottle (Nt) were counted. After each test the "Y" glass tube and the gas washing bottles were washed with water, rinsed with acetone and dried at $80^{\circ} \mathrm{C}$ for $1 \mathrm{~h}$. Each treatment was replicated four times and percentage repellency (PR) values were computed using the methods of Jilani et al. (1988) as:

$$
\mathrm{PR}(\%)=\underline{\mathrm{Nc}-\mathrm{Nt}} \times 100
$$

$\mathrm{N}$

Where, Nc is the individuals in the control bottle (untreated seeds).

$\mathrm{Nt}$ is the individuals on the treated bottle.

$\mathrm{N}$ is the total number of insects tested.

\subsection{Fumigation toxicity}

The fumigation toxicity of the essential oil was tested following the method of Wang et al. (2001) with some modification. Wide mouth bottles of 1-liter capacity with lids were used as exposure chamber. Filter papers of 9mm diameter were treated with 1, 2 and 3ml of essential oil at the rate of $12 \mathrm{mg}, 60 \mathrm{mg}, 300 \mathrm{mg}$ dissolved in $10 \mathrm{ml}$ of acetone; the same amount of acetone alone was applied as control. The solvent was allowed to evaporate for 20minutes and then the filter paper was placed at the bottom of a 1-liter glass bottle. Twenty insects in small nylon mesh bag with $100 \mathrm{~g}$ food substrate were hung at the center of the glass bottle $(7 \mathrm{~cm}$ high) above the 
filter paper. The bottles were then closed tightly with a lid. Each treatment with respective control was replicated five times. Mortality was checked after 24hrs.

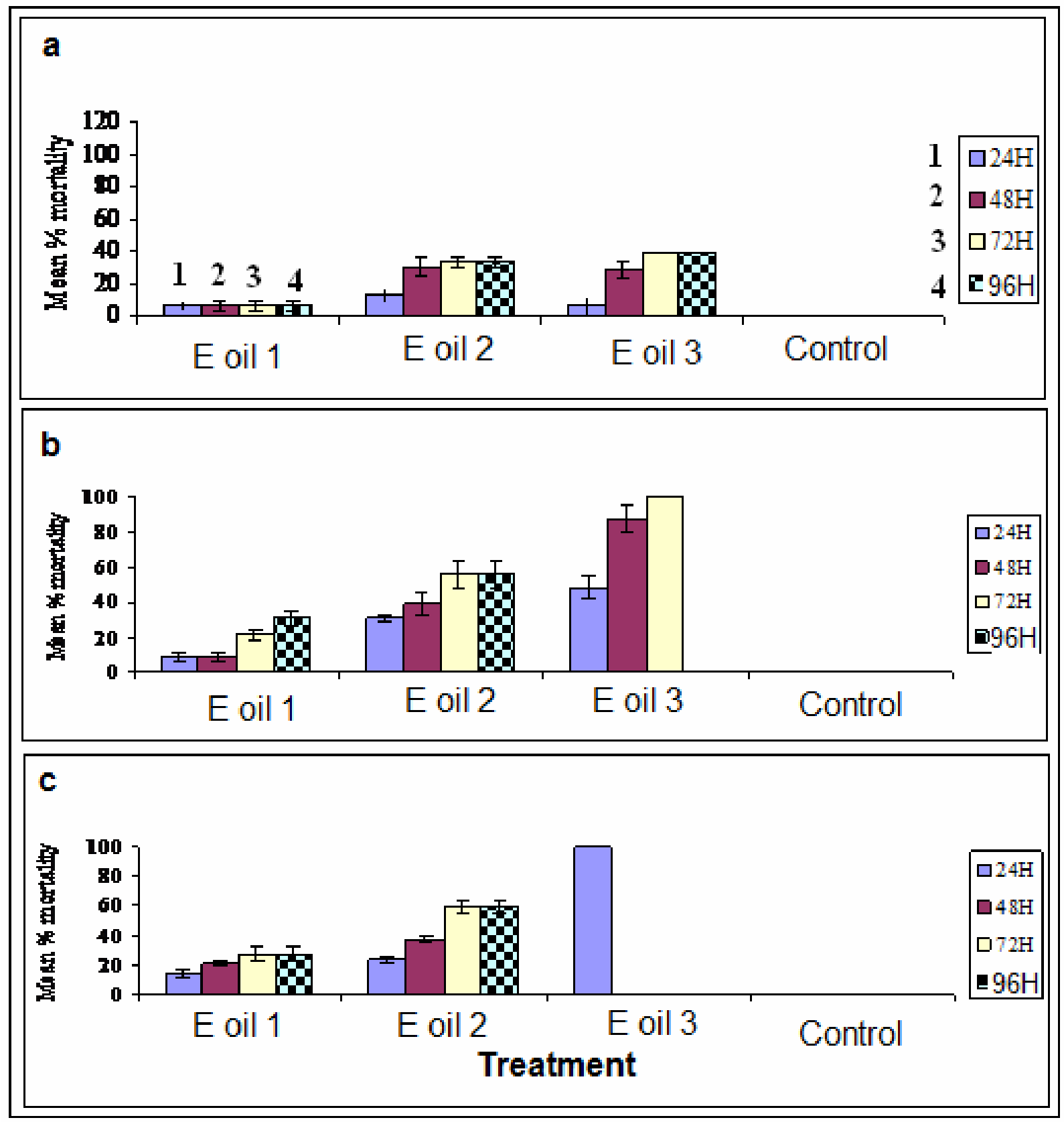

Figure 1 . Mean \% mortality of $Z$. Subfasciatus due to essential oil of $C$. sinensis applied at rate of $1 \mathrm{ml}$ (a), 2ml (b) and 3ml (c) after different times of exposure (E oil1 = Essential oil at 0.03g; E oil 2 = Essential oil at 0.15g; and E oil 3 = Essential oil at 0.75g). 


\section{RESULTS}

\subsection{Toxicity of the Plant Material}

Acetone, ethanol, petroleum ether and water extracts of Citrus sinensis at all rates was not toxic. It was only the essential oil of $C$. sinensis that showed significant effect $(P<0.05)$ at all levels. At the highest rate $(750 \mathrm{mg} /$ filter) applied at 3ml gave 100\% mortality of Z. subfasciatus after 24 hour exposure time (Fig. 1).

\subsection{Adult Mortality in the Grain}

The essential oil of $C$. sinensis at the highest dose of $0.75 \mathrm{~g} / 250 \mathrm{~g}$ of haricot bean gave $67.4 \%$ mortality after 96 hours of exposure (Table 1). C. sinensis applied as powder were also toxic at higher dosage of $15 \mathrm{~g} / 250 \mathrm{~g}$ of grain causing 65.95\% mortality after 96 hour of exposure (Table 1). The result of this experiment showed that all treatments of the essential oil of orange peel were relatively toxic to Z. subfasciatus.

\begin{tabular}{|c|c|c|c|c|c|}
\hline \multirow[t]{2}{*}{ Treatment } & \multirow{2}{*}{$\begin{array}{c}\text { Dosage } \\
(\mathrm{g} / 250 \mathrm{~g})\end{array}$} & \multicolumn{4}{|c|}{ Mean \% adult mortality, $h$ after exposure } \\
\hline & & 24 & 48 & 72 & 96 \\
\hline \multicolumn{5}{|l|}{ Orange powder } & $45.00 \pm 3.33 b$ \\
\hline \multicolumn{6}{|c|}{$0+10-2.0504$} \\
\hline \multicolumn{6}{|l|}{$15 g$} \\
\hline \multicolumn{6}{|c|}{ Orange essential oil } \\
\hline $0.03 g$ & 0.03 & $21.14 \pm 2.70 b$ & $39.15 \pm 2.97 c d$ & $53.81 \pm 2.97 \mathrm{~cd}$ & $56.79 \pm 0.00 \mathrm{~cd}$ \\
\hline $0.15 \mathrm{~g}$ & 0.15 & $26.07 \pm 4.27 \mathrm{bc}$ & 45.96 $\pm 2.54 \mathrm{de}$ & $61.33 \pm 3.08 \mathrm{~d}$ & $61.33 \pm 3.08 \mathrm{cde}$ \\
\hline $0.75 \mathrm{~g}$ & 0.75 & $47.89 \pm 2.88 \mathrm{~d}$ & $57.00 \pm 3.65 \mathrm{e}$ & $63.55 \pm 2.08 \mathrm{~d}$ & $67.40 \pm 2.34 \mathrm{e}$ \\
\hline \multicolumn{6}{|c|}{ Pirimiphos-methyl } \\
\hline Control & 0 & $0.00 \pm 0.00 a$ & $0.00 \pm 0.00 \mathrm{a}$ & $0.00 \pm 0.00 \mathrm{a}$ & $0.00 \pm 0.00 \mathrm{a}$ \\
\hline
\end{tabular}

Mean with in a column followed by different letters are significantly different, $P<0.05 \%$, Tukey student test (HSD). Nob = No observation

\subsection{Progeny emergence}

The numbers of F1 progeny produced in each treatment were significantly low compared to the number of progeny produced in control. All levels of the powder of $C$. sinensis peels caused significant reduction in progeny emergence of $Z$. subfasciatus $(\mathrm{P}<0.05)($ Table 2$)$. No emergence 
of adult progeny was observed from pirimiphos-methyl treated haricot beans. A similar result was obtained with haricot beans treated with $750 \mathrm{mg}(0.3 \%)$ of essential oil, but there was no significant difference $(\mathrm{P}>0.05)$ between the mean number of $\mathrm{F}_{1}$ adult progeny that emerged in beans treated with 30, 150 and 750mg (Table 2). The result of this experiment showed that all treatments of essential oil were effective as the standard insecticide, pirimiphos-methyl, by significantly reducing $\mathrm{F}_{1}$ progeny emergence.

\subsection{Damage assessment}

Weight loss assessments result of treated and untreated grains are shown in table 2. All the treatments significantly reduced weight loss compared to the untreated check 45 days after introduction of Z. subfasciatus into treated and untreated beans. No weight loss of stored haricot beans was observed in seeds that were treated with pirimiphos-methyl at a recommended rate. The highest dosage of the powder peel protected the haricot beans against feeding by $Z$. subfasciatus which resulted in no noticeable feeding damage on seeds. However this result was achieved at a minimum dose (30mg) for essential oil of $C$. sinensis. The present finding showed that essential oil of orange peels effectively reduced the grain damage weight loss even at lower dose than the standard check pirimiphos-methyl at recommended rate.

\begin{tabular}{|llll|}
\hline $\begin{array}{l}\text { Table 2. Mean number of F1 progeny produced and weight loss caused by Z. subfasciatus on } \\
\text { seeds treated with powder and essential oil of C. sinensis. }\end{array}$ \\
\hline Treatments & Dosage (g/250g) & $\begin{array}{l}\text { Mean number of } \\
\text { progeny }\end{array}$ & Mean \%weight loss \\
\hline Orange powder & 5 & $31.66 \pm 5.81^{\mathrm{b}}$ & $0.53 \pm 0.09^{\mathrm{b}}$ \\
\hline & 10 & $17.66 \pm 0.88^{\mathrm{ab}}$ & $0.38 \pm 0.08^{\mathrm{ab}}$ \\
\hline & 15 & $13.66 \pm 1.45^{\mathrm{ab}}$ & $0.00 \pm 0.00^{\mathrm{a}}$ \\
\hline Orange essential oil & 0.03 & $1.00 \pm 1.00^{\mathrm{a}}$ & $0.00 \pm 0.00^{\mathrm{a}}$ \\
\hline & 0.15 & $0.66 \pm 0.66^{\mathrm{a}}$ & $0.00 \pm 0.00^{\mathrm{a}}$ \\
\hline & 0.75 & $0.00 \pm 0.00^{\mathrm{a}}$ & $0.00 \pm 0.00^{\mathrm{a}}$ \\
\hline Pirimiphos-methyl & 0.125 & $0.00 \pm .00^{\mathrm{a}}$ & $0.00 \pm 0.00^{\mathrm{a}}$ \\
\hline Control (untreated) & 0 & $123.33 \pm 6.88^{\mathrm{e}}$ & $2.33 \pm 0.09^{\mathrm{e}}$ \\
\hline
\end{tabular}

Mean with in a column followed by different letters are significantly different, $P<0.05 \%$, Tukey student test (HSD).

\subsection{Fumigation toxicity}

The result on fumigant toxicity of essential oil of $C$. sinensis towards $Z$. subfasciates is presented in table 3. No dead insects were observed at lower dose of $0.012 \mathrm{mg} / 10 \mathrm{ml}$ of acetone applied at all levels 1, 2 \& 3ml/filter paper. The highest dose of essential oil showed significantly higher 
( $\mathrm{P}<0.05$ ) mortality. Particularly essential oil of $0.3 \mathrm{~g}$ applied at the rate of 2 and $3 \mathrm{ml}$ per filter paper induced $100 \%$ mortality of $Z$. subfasciatus. Acetone treated controls did not cause any significant mortality of the bruchids at 1, 2 and 3ml level of application.

\begin{tabular}{|lll|}
\hline \multicolumn{3}{|l|}{ Table 3. Fumigant toxicity of $C$. sinensis essential oil treated seeds to Z. subfasciates. } \\
\hline Treatments (g/100g of seed) & Dose ( $\mathbf{m l} /$ filter) & \% mortality after 24h exposure \\
\hline 0.06 gram & $1 \mathrm{ml}$ & $0.25 \pm 0.25 \mathrm{a}$ \\
\hline & $2 \mathrm{ml}$ & $0 \pm 0.00 \mathrm{a}$ \\
\hline & $3 \mathrm{ml}$ & $18.75 \pm 2.39 \mathrm{~b}$ \\
\hline $0.3 \mathrm{gram}$ & $1 \mathrm{ml}$ & $26.25 \pm 1.25 \mathrm{c}$ \\
\hline & $2 \mathrm{ml}$ & $100.00 \pm 0.00 \mathrm{~d}$ \\
\hline & $3 \mathrm{ml}$ & $100.00 \pm 0.00 \mathrm{~d}$ \\
\hline Control (acetone treated) & $3 \mathrm{ml}$ & $0.00 \pm 0.00 \mathrm{a}$ \\
\hline
\end{tabular}

Mean with in a column followed by different letters are significantly different, $P<0.05 \%$, Tukey student test (HSD).

\subsection{Repellency}

Table 4 shows the mean repellency values for the test materials at different doses. The percent repellency obtained with out choice was less than with choice test. All the treatments showed significant repellent effect against $Z$. subfasciatus $(\mathrm{P}<0.05)$.

\begin{tabular}{|lrlc|}
\hline \multicolumn{2}{|l|}{$\begin{array}{l}\text { Table 4. Mean percentage repellency of different plant materials and dose levels } \\
\text { for Z. subfasiatus. }\end{array}$} & \multicolumn{2}{c|}{$\begin{array}{c}\text { Mean \% repellency (PR) } \\
\text { With choice }\end{array}$} \\
\hline Treatments (g/100gm seeds) & \multicolumn{1}{c|}{ No choice } & $25.00 \pm 1.73 \mathrm{de}$ \\
\hline Orange powder & $2 \mathrm{~g}$ & $25.00 \pm 4.04 \mathrm{de}$ & $33.80 \pm 1.97 \mathrm{f}$ \\
\hline & $4 \mathrm{~g}$ & $33.25 \pm .85 \mathrm{e}$ & $38.45 \pm 1.65 \mathrm{f}$ \\
\hline $6 \mathrm{~g}$ & $32.50 \pm 1.44 \mathrm{e}$ & $33.27 \pm 2.03 \mathrm{ef}$ \\
\hline Orange oil & $0.012 \mathrm{~g}$ & $25.75 \pm 2.56 \mathrm{de}$ & $37.60 \pm 0.90 \mathrm{f}$ \\
\hline & $0.06 \mathrm{~g}$ & $33.50 \pm 2.39 \mathrm{e}$ & $53.75 \pm 1.37 \mathrm{f}$ \\
\hline Control & $0.3 \mathrm{~g}$ & $37.87 \pm 0.96 \mathrm{f}$ & $0.00 \pm 0.00 \mathrm{a}$ \\
\hline
\end{tabular}

Mean with in a column followed by different letters are significantly different, $P<0.05 \%$, Tukey student test (HSD).

\section{DISCUSSION}

Orange peel oil at high concentration level of $750 \mathrm{mg}$ applied at $3 \mathrm{ml}$ caused $100 \%$ mortality of $Z$. subfasciatus exposed to treated beans at all concentrations used. Four days after introduction, 
adult mortality of the insect was 67\% (orange peel oil) and 66\% (orange peel powder)., where, as pirimiphos-methyl caused 100\% mortality with-in 24 hour.

The toxicity of $C$. sinensis peel oil may be attributed to d-limonene (Sharaby, 1988). Tripathi et al. (2003) reported the contact toxicity of d-limonene with $\operatorname{LD}_{50} 74.73,85.37$ and 79.78 for $R$. dominica, S. oryzae and T. castaneum. An over-all test of efficacy between the treatments has shown that mortality was directly related to the dosage and time. This indicates that higher dosage is more efficient in management of pests. In case of the sun dried powder, the orange peel seems very promising, though significant result is gained at higher dosage than the standard rate of 5\% suggested for most botanicals for storage pest management. Belmain and Stevenson (2001) also reported effective use of $C$. sinesis powder against legume pests. The effectiveness of the orange peel powder is probably due to silica or silica like component, which are abrasive and the ability of the particles to adhere to the grain.

All the treatments caused significant reduction of F1 adult emergence compared to control. The extent to which the orange peel products affected the survival of the subsequent progeny was found to vary among them. In the progeny count, only those newly emerged adults were considered which were alive. This indicated that the active ingredients of botanicals which are responsible for the toxicity of the plant kill the insects gradually. Citrus sinesis peel oil was superior to untreated and powder causing 100.00, 99.44 and $99.00 \%$ reduction in adult emergence at $0.75,0.15$ and $0.03 \mathrm{~g} / 250 \mathrm{~g}$ of haricot bean. The study showed that orange peel oil is even better than pirimiphos-methyl causing 100\% reduction of F1 emergence at lower dose. The current findings are similar to the results of Tripathi et al. (2003) who has also reported oviposition reduction effect of orange peel oil against T. castaneum by $94.5 \%$. Similarly, Sharaby (1988) also reported reduced oviposition and egg hatching of potato tuber moth, Phthorimaea operculella exposed to $220 \mu \mathrm{l}$ of the oil. It is also reported by Levinson et al. (2003) that orange peel oil at $1 \mathrm{ml}$ suppressed oviposition of Mediterianin fruit fly, Ceratitis capitata. The present study also shows that orange peel oil has strong oviposition deterrent effect against Z. subfasciatus. Powdered sun dried orange powder were also effective in reducing F1 adult emergence though not effective as orange peel oil and pirimiphos-methyl.

Significant reductions in feeding damage which indicates the higher protectant potential of these materials against insect damage were observed. The plant materials were highly effective significantly reduced damage to haricot bean when compared to control. It appears therefore that 
orange peel oil has insecticidal properties which accounts for much higher levels of effectiveness. Furthermore, orange peel powder at 15g/250g of haricot bean seed also protected the grain from damage by hundred percent, strongly suggesting the presence of physical interfering agents in orange peel powder.

Orange peel oil showed highest fumigant toxicity causing $100 \%$ mortality at $0.3 \mathrm{~g} / 100 \mathrm{~g}$ of haricot bean applied at $3 \mathrm{ml}$ adjusted to $24 \mathrm{~h}$ exposure. The fumigant toxicity decreased with decreasing concentration. The orange peel oil has been reported to have fumigant toxicity 13 times more than that of methyl bromide (Tripathi et al., 2003). The present study also showed that orange peel has strong fumigant toxicity effect against the Z. subfasciatus. Keita et al. (2001) reported that the mode of the action of fumigant toxicity of essential oil against insects might be the inhibition of acetylcholinesterase.

Using essential oils as a fumigant for stored grain and legumes could be particularly relevant as methyl-bromide is removed from use. However, there is only very limited evidence demonstrating their ability to penetrate through grain bulks which must occur if plant extracts are to emulate fumigant gases. In addition, the understanding of sorption and residue on target grain are important issue to use essential oils as a potential fumigant (Lee et al., 2003).

The repellency effect of Citrus sinensis peels oil was relatively lower. This suggests that the active compounds which acted as repellent and fumigant might be chemically different.

The result of the current study suggested that materials derived from Citrus sinensi , may be used as pulse protectant against Z. subfasciatus for small scale farmers. Therefore, investigation on incorporating, improving and adopting for the control of stored product insects need to be investigated.

\section{CONCLUSION}

This study indicated Citrus sinensis posses toxicity, feeding and ovipositional deterrent effect on Z. subfasciatus. The $C$. sinensis oil and its sun dried powder significantly reduced the F1 progeny and weight loss. Furthermore, the study showed the peel oil possessed contact and fumigant toxicity on the Z.subfasciatus. Hence all the result of this study indicated that orange peel may be used as a potential stored grain protectant. 


\section{ACKNOWLEDGMENT}

I am thankful and grateful to my beloved guide late Dr. Bekele Jembere for his immense support and unending encouragement. Department of Biology of Addis Ababa University is also acknowledged for the provision of laboratory facilities. I also thank Melkassa Agricultural Research Center for cooperation.

\section{REFERENCES}

Adane Kassa \& Abrham Tadesse. 1996. Evaluation of some botanical against the maize weevil (Sitophilus zeamais Motsch.) on stored sorghum at Bako. In: Eshetu Bekele, Abdurahman Abdulahi and Aynekulu Yemane (eds.), Proceedings of the third annual conference of the Crop Protection Society of Ethiopia (CPSE), Addis Ababa, Ethiopia, pp. 120-126.

Bayeh Mulatu \& Tadesse Gebremedhin. 1996. Suppressing effect of different botanicals on the Adzuki Bean Beetle (Callosobruchus chinensis L.). In: Eshetu Bekele, Abdurahman Abdulahi and Aynekulu Yemane (eds.), Proceedings of the third annual conference of the crop protection society of Ethiopia. (CPSE), Addis Ababa, Ethiopia, pp. 134-140.

Bekele, A. J., Obeng-Oforis, D \& Hassanali, A. 1997. Evaluation of Ocimum kenyense (Ayobangira) as source of repellents, toxicants and protectants in storage against three major stored product insect pests. J. Applied Entomology, 121: 169-173.

Belmain, S \& Stevenson, P. 2001. Ethnobotanicals in Ghana: Reviving and modernizing age- old farmer practice. Pesticide Outlook, pp. 233- 238.

Boxall, R. A., Brice, J.R., Taylor, S.J \& Bancroft, R.D. 2002. Technology and management of storage. In: Golob, P., Farrell, G. and Orchard, J.E. (eds.), Crop Post-Harvest: Science and Technology, Principles and Practice. Natural Resource Institute, University of Greenwich, 1:141-232.

Cobbinah, J.R \& Appiah-Kwarteng, J. 1989. Effects of some neem products on stored maize weevil, Sitophlius zeamias Motsch. J. Applied Entomology, 10: 89-92.

Don-Pedro, K. N. 1985. Toxicity of some Citrus peels to Dermestes maculates Deg. and Callosobruchus maculates (F.). J. Stored Product Research, 81: 31-34.

EARO. (Ethiopian Agricultural Research Organization). 1999. EARO Annual Report 1997/98. EARO, Addis Ababa, Ethiopia. 
El Atta, H. A \& Ahmed, A. 2002. Comparative effects of some botanicals for the control of the seed weevil Caryedon serratus Oliver (Col., Bruchidae). J. Applied Entomology, 126: 577-583.

El-Sayed, F. M. A \& Abdel-Razik, M. 1991. Citrus oil as protectant against infestation by Callosobruchus maculates (F.) (Coleoptera: Bruchidae). Bulletin Entomology Society of Egypt Economics, 14: 423-427.

Emana Getu.1999. Use of botanical plants in the control of stored maize grain insect pests in Ethiopia. In: Maize production technology for the future: challenges and opportunities: Proceedings of the sixth eastern and southern Africa regional maize conference, CIMMYT and EARO, Addis Ababa, Ethiopia, pp. 105 - 108

FAO. 1985. Prevention of post harvest food losses. Training series no. 10. Food and Agriculture Organization of the United Nations. Rome, Italy.

Ferede Negasi \& Tsedeke Abate. 1995. Progress in Bean Bruchid Management. In: Habtu Assefa (ed.), Proceeding of the $25^{\text {th }}$ anniversary of Nathreth research center: 25 years of experience in low land crops research, Nazareth, Ethiopia. Nazareth agriculture research center, pp. 181-194.

Firdissa Eticha \& Abraham Tadesse. 1998. Effect of some botanical \& other materials against the maize weevil (Sitophilus zeamais Motsch) on stored maize. In: Maize production technology for the future: challenges and opportunities: of the sixth Eastern and Southern Africa Regional Maize Conference, Addis Ababa. Ethiopia, pp. 101-104.

Firdissa Eticha \& Abraham Tadesse.1999. Insect pests of farm-stored sorghum in the Bako area. Pest Management. Journal of Ethiopia, 3: 53 - 60.

Glob, P., Moss, C., Dales, M., Fidgen, A., Evans, J., Gudrups, I \& NRI. 1999. The use of spices and medicinals as bioactive protectants for grains. FAO Agricultural Services Bulletin, 137: 289.

Jembere, B. 2002. Evaluation of the toxicity potential of Milletia ferruginea (Hochest) Raker against Sitophilus zeamais (Motsch.). Intenational J. Pest Management, 48: 29-32.

Jembere, B., Obeng-Ofori, D \& Hassanali, A. 1995. Products derived from the leaves of Ocimum kilimandsharicum (Labiate) as Post-harvest grain protectants against the infestation of three major stored product insect pests. Bulletin of Entomological Research, 85: 361367. 
Jilani, G.R., Sexana, C \& Rueda, B.P. 1988. Repellent and growth-inhibiting effects of tumeric oil, sweetflag oil, neem oil and margasan on red flour beetle (Coleoptera: Tenebrionidae). J. Economic of Entomology, 81: 1226-1230.

Karr, L.L \& Coats, J.R. 1988. Insecticidal properties of d-limonene. J. Pesticide Science, 13: 287-290.

Keita, S.M., Vincent, C., Schmit, J., Arnason, J.T \& Belanger, A. 2001. Efficacy of essential oil of Ocimum basilicum L. and O. gratissimum L. applied as an insecticidal fumigant and powder to control Callosobruchus maculates (Fab.) (Coleoptera: Bruchidae). J. Stored products Research, 37: 339-349.

Lee, B., Annis, P.C \& Tumaalii, F. 2003. The potential of 1,8-cineole as a fumigant for stored wheat. In: Wright, E.J, Webb, M.C. and Highley, E. (eds.), Stored grain in Australia. Proceedings of the Australian Postharvest Technical Conference, CSIRO Stored Grain Research Laboratory, Canberra.

Levinson, H., Levison, A \& Osterried, E. 2003. Orange- derived stimuli regulating oviposition in the Mediterranean fruit fly. J. Applied Entomology, 127: 269-275.

Mc Farlance, J.A. 1988. Storage methods in relation to post-harvest losses in cereals. Insect Science and its Application, 9: 747-754.

Mekuria Tadesse.1995. Botanical insecticides to control stored grain insects with special reference to weevils (Sitophilus spp.) on maize. In: Proceedings of the Third Annual Conference of Crop Protection Society of Ethiopia, Addis Ababa, Ethiopia, pp.134-140.

Mwaiko, G.L \& Savaeli, Z.X. 1992. Citrus peel oil extracts as mosquito larvae insecticides. East Africa Medical Journal, 69: 223-227.

Roomi, M.W \& Atiquiddin, M. 1977. Observations on the repellency of 'neem' plant, Melia azadirachta L. on some stored-grain pests from Pakistan. J. Applied Entomology, 84 : 124-129.

Schoonhoven, A.V. 1978. Use of vegetable oils to protect stored beans from bruchid attack. J. Economic Entomology, 71: 254-256.

Slim. M.N. 1993. Studies of the control of the bean bruchids Acanthoscelides obtectus (Say) and Zabrotes subfasciatus (Boheman) Bruchidae: Coleoptera in Eastern in Eastern Africa. In: Smithson, J. B. (ed.), Proceedings of third multidisciplinary workshop on bean research in Eastern Africa, Thika, Kenya. 
Sharaby, A. 1988. Effect of orange, Citrus sinesis (L.) peel oil on reproduction in Phthorimea operculella (Zell). Insect Science and its Application, 9: 201-203.

Tripathi, A.K., Prajaoati, V., Khanuja, S.P \& Kumar, S. 2003. Effect of d-Lemonene on three stored-product beetles. J. Economic Entomology, 96: 990-995.

Wang, J., Tsai, J.H., Ding, W., Zhao, Z \& Li, L. 2001. Toxic effects of six plant oils alone and in combination with controlled atmosphere on Liposcelis bostrychophila (Psocoptera: Liposcelidiae). J. Economic Entomology, 94: 1296-1301.

Weinzierl, R \& Henn, T. 1992. Alternatives in insects management: Biological and Biorational Approaches. University of Illinois, Urban-Champaign, North Central Regional Extention publication 401.

Yemane Kidane \& Yilma Habte. 1998. Food and grain losses in traditional storage facilities in three areas of Ethiopia. In: Towards food and nutrition strategy for Ethiopia. Proceedings of the National Workshop on Food Strategies for Ethiopia. Alemaya University of Agriculture, Alemaya, Ethiopia, pp. 407- 430. 